\title{
Studies on Paraoxonase-1 Isolated from Amniotic Fluid and its Effect Against Cisplatin-Induced Hepatotoxicity and Cardiotoxicity in Rats
}

\author{
Luay A. Al-Helaly \\ Department of Chemistry / College of Science / Mosul University
}

Email: Luayhelaly@yahoo.com

(Received 5/1/2014; Accepted 5/5/2014)

\begin{abstract}
Paraoxonase-1 (PON1) was isolated from the amniotic fluid of normal pregnancies at last week of gestation. One proteinous band had been isolated by gel filtration sephadex (G-50) from the protein precipitate produced by ammonium sulfate saturation (67\%) after dialysis. The product from (G-50) gave two bands by sephadex (G-100). It was found that the first peak (Peak A) had higher activity for (PON1). The apparent molecular weights of the isolated PON1 using gel filtration chromatography and SDS-PAGE was $(43873 \pm 350)$ and $(43682 \pm 278)$ Dalton respectively.

The results also showed that the optimum conditions of PON1 was obtained at $(80 \mu \mathrm{g} / \mathrm{ml})$ of protein as a source of the enzyme using $(10 \mathrm{mmol} / \mathrm{l})$ of paraoxon as a substrate, Tris- $\mathrm{HCl}$ buffer $(0.14 \mathrm{~mol} / \mathrm{l})$ as a buffer at $\mathrm{pH}(8.0)$ and incubation for $(7)$ minutes at $\left(45^{\circ} \mathrm{C}\right)$. Using lineweaverBurk plot, the values of maximum velocity $\left(V_{\max }\right)$ and Michaelis constant $\left(K_{\mathrm{m}}\right)$ were $(80.0 \mu \mathrm{mol} /$ $\mathrm{min})$ and $(3.79 \mathrm{mmol} / \mathrm{l})$ respectively.

The protective effect of PON1 against cisplatin-induced hepatotoxicity and cardiotoxicity by intraperitoneal injection of $(10 \mathrm{mg} / \mathrm{kg})$ cisplatin were evaluated in 35 male albino white rats classified into 5 groups. The rats were treated with $0.5 \mathrm{mg} / \mathrm{kg} / \mathrm{day}$ or $1 \mathrm{mg} / \mathrm{kg} / \mathrm{day}$ of isolated PON1 injected intraperitonealy for 5 successive days before and 5 successive days after induction of toxicity. The results showed a significant reduction in the levels of alkaline phosphatase (ALP), aspartate aminotransferase (AST), alanine aminotransferase (ALT), creatine kinase (CK), total bilirubin(TB) and malondialdehyde(MDA) in comparison with the cisplatin treated animals. It was concluded that (PON1) protects the liver and heart against the toxicity induced by this cytotoxic drug.
\end{abstract}

Keywords: Isolation, Paraoxonase-1, Amniotic fluid, Cisplatin.

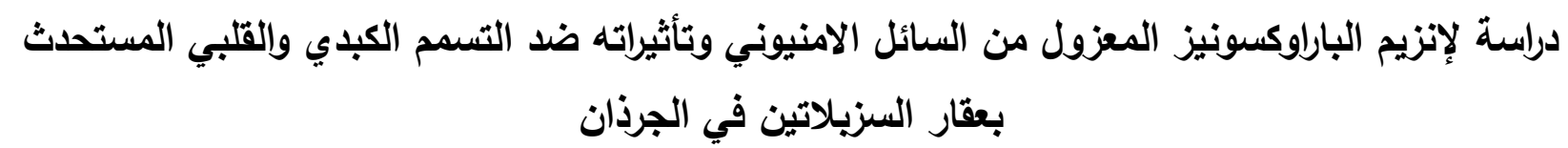

الملخص

$$
\begin{aligned}
& \text { عزل إنزيم الباراوكسونيز من السائل الامنيوني لنساء حوامل طبيعيين في الأسبوع الأخير من الحمل. إذ نم فصل حزمة } \\
& \text { بروتينية واحدة بتقنية الترشيح الهلامي سيفادكس نوع G-50 للراسب البروتيني الناتج من عملية الترسيب بكبريتات الامونيوم }
\end{aligned}
$$

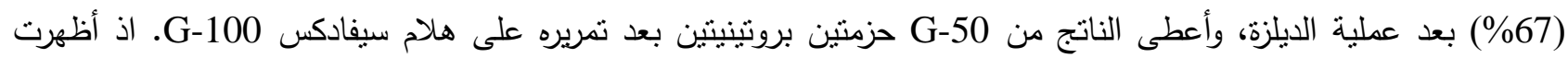

$$
\begin{aligned}
& \text { الحزمة الأولى (قمة A) فعالية عالية للإنزيم PON1، بعدها قدر الوزن الجزيئي التقريبي للإنزيم باستخدام تقنيتي الترشيح الهلامي }
\end{aligned}
$$

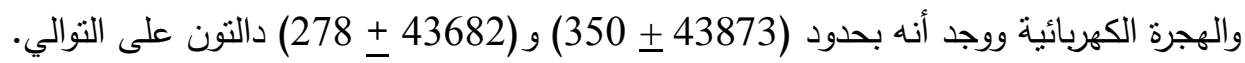

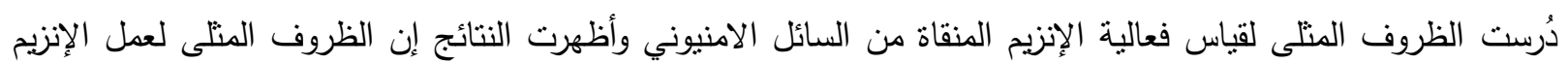

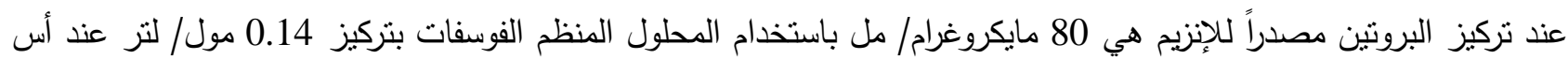




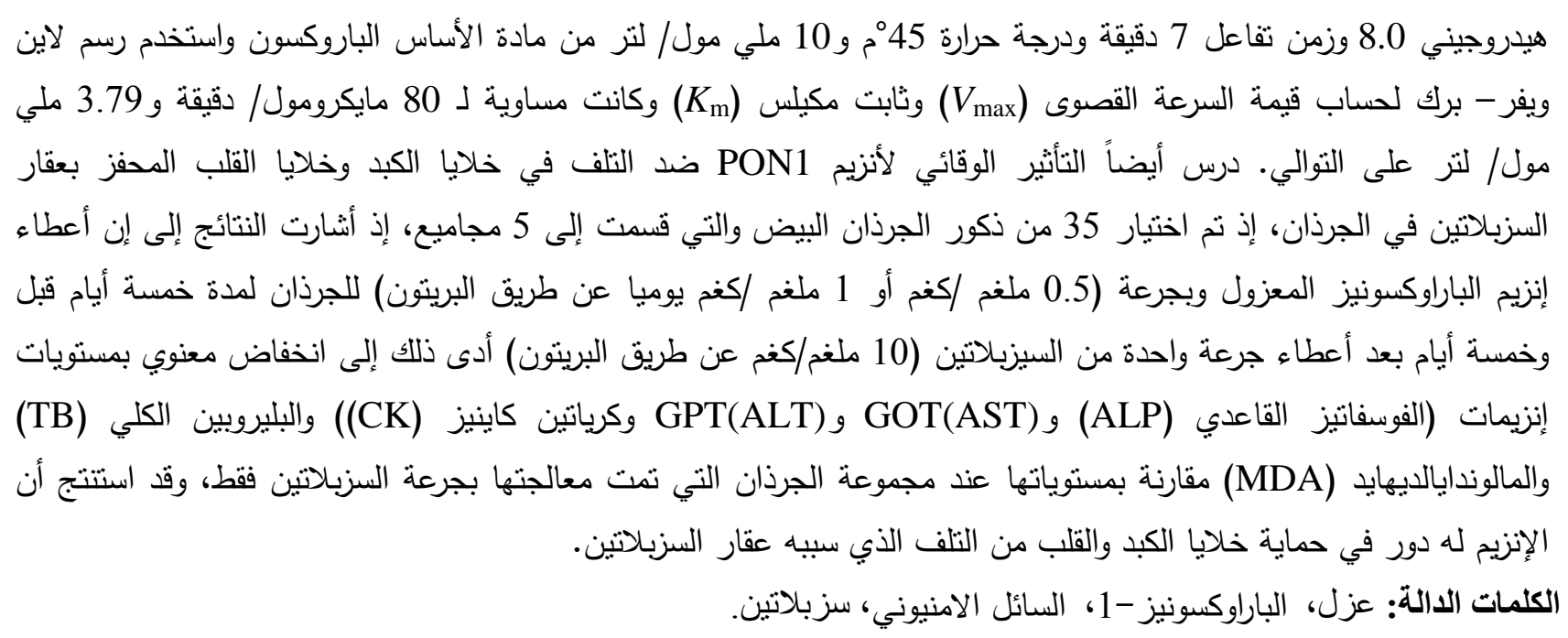

INTRODUCTION

Paraoxonase-1 (PON1, EC 3.1.8.1) is a Calcium dependent mammalian enzyme that is synthesized primarily in the liver and is secreted into the serum where it is associated with high density lipoproteins (HDLs) and has a protective effect against the oxidation of low density lipoproteins (LDLs). Beside antioxidant and antiatherogenic properties, PON1 also is a detoxifier that can hydrolyze toxic organophosphates (Sanghera et al., 1998). It is a member of three gene family consisting of PON1, PON2 and PON3 located on human chromosome 7 (Primo-Parmo et al., 1996). Several studies have shown that PON1 can bind reversibly to organophosphate substrates which it hydrolyze (Arslan et al., 2011 ). Environmental factors that change PON1 activity include tobacco consumption, which has been reported to depress PON1 activity and concentration(Mackness et al., 1996). Human paraoxonase (PON) is believed to protect lipoproteins against oxidative modification (Gowri et al., 1999).

Amniotic fluid (AF), the protecting liquid contained in the amnion cavity, is an essential component for fetal development and maturation during pregnancy. It also plays a significant defensive role as part of the innate immune system since AF has an organized pool of antimicrobial peptides against common bacterial and fungal pathogens (Akinbi et al., 2004). AF is composed of 98\% water and electrolytes, proteins, peptides, carbohydrates, lipids and hormones, Human AF has been shown to contain 412 proteins (Tsangaris et al., 2006), It provide the physical environment, which protects the growing fetus (Verburg et al., 2007). Human phosphate binding protein is an apolipoprotein, 38-45-kDa glycosylated protein, found in human AF (Tsangaris et al., 2006) for example PON1 (Alam et al., 2009).

Cisplatin is a platinum-based drug (Ali and Al Moundhri, 2006), which is one of the most effective anti-neoplastic agents used for treatment of testicular, ovarian, bladder, cervical, lung, and neck cancers (Abu-Surrah and Kettunen, 2006). The cytotoxic effect of cisplatin is believed to result mainly from its interaction with DNA, via the formation of covalent adducts between certain DNA bases and the platinum compound (Yousef et al., 2009). However, despite it's a clinical usefulness, cisplatin treatment has been associated with several toxic side effects including nephrotoxicity (De Jongh et al., 2003), hepatotoxicity and cardiotoxicity (Al-Majed, 2006).

The aim of this research is to provide a detailed study of (PON1) involving isolation, purification from AF using different biochemical techniques then characterization of PON1 and showing its effects on hepatotoxicity and cardiotoxicity in rats induced by cisplatin drug. 


\section{MATERIALS AND METHODS}

\section{Assay the activity of plasma paraoxonase-1 (PON1)}

PON1 assays were done by formation of $p$-nitrophenol and measured by its absorbance at 405 $\mathrm{nm}$ for $5 \mathrm{~min}$ (Equation Below). Assay buffer contained $0.125 \mathrm{~mol} / \mathrm{l}$ Tris- $\mathrm{HCl}(\mathrm{pH} \mathrm{8.5),} 1.25$ $\mathrm{mmol} / \mathrm{C} \mathrm{CaCl}_{2}$, and $1 \mathrm{~mol} / \mathrm{l} \mathrm{NaCl}(\mathrm{pH} 8.5)($ Eckerson et al., 1983; Furlong et al., 2001). For each set of assays, $6 \mathrm{mmol} / \mathrm{l}$ freshly prepared paraoxon $(O, O$ diethyl- $O$ - $p$-nitrophenylphosphate; SigmaAldrich Chemical Co.) substrate solution of $120 \mathrm{mmol} / \mathrm{l}$ paraoxon in acetone diluted with 0.125 $\mathrm{mmol} / \mathrm{l}$ Tris- $\mathrm{HCl}$ was used. Paraoxon stock solution was handled very cautiously with protective measures. The assay tube contained $750 \mu \mathrm{L}$ of Tris buffer, $50 \mu \mathrm{L}$ of sample (1:2 diluted with water) and $200 \mu \mathrm{L}$ of $6 \mathrm{mmol} / 1$ paraoxon. The reaction was initiated at $37^{\circ} \mathrm{C}$ by the addition of the substrate solution, and using a CE 1021 Ultra Violet and Visible Spectrophotometer, absorbance was continuously monitored at $405 \mathrm{~nm}$. The PON1 unit was defined as the enzyme quantity that disintegrates $1 \mu \mathrm{mol}$ paraoxon substrate in one minute (Eckerson et al., 1983).<smiles>CCOP(=O)(OCC)Oc1ccc([N+](=O)[O-])cc1</smiles>
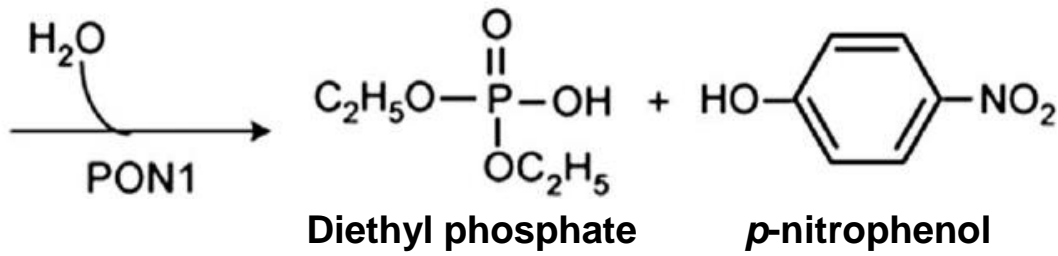

\section{Purification of paraoxonase-1 (PON1) from amniotic fluid}

The method given here has yielded an enzyme preparation acceptable for amniotic fluid. All steps were performed at $4{ }^{\circ} \mathrm{C}$ unless otherwise stated.

\section{Step I: Collection of amniotic fluid}

Pregnancies at last week of gestation were pooled, which were planned from amniocentesis to evaluate other gestational diseases. The specimens were obtained from the Al-Betool hospital, Mosul/ Iraq. A 23-G spinal needle was used to aspirate the amniotic fluid from the abdomen by a medical professional specialized in the field of prenatal diagnostic procedures and fetal medicine. Samples (21) were centrifuged at $20,000 \mathrm{~g}$ for $30 \mathrm{~min}$, and the supernatant was used to isolate PON1.

\section{Step II: Ammonium sulfate fractionation}

Protein was precipitated from $220 \mathrm{ml}$ supernatant of the AF using $67 \%$ ammonium sulfate $\left(\mathrm{NH}_{4}\right)_{2} \mathrm{SO}_{4}$ saturation (Protein salting out) (Robyt and White, 1987; Harvey and Ferrier, 2014).

\section{Step III: Cooling ultracentrifuge separation}

The suspension produced from step II was centrifuged at $9000 \mathrm{~g}$ for (45) $\min$ at $-4^{\circ} \mathrm{C}$ to avoid denaturation. The protein in precipitate and supernatant are determined using by the modified Lowry method (Schacterle and Pollack, 1973), PON1 activity was determined in each fraction(Eckerson et al., 1983).

\section{Step IV: Dialysis}

Dialysis was performed using a semi permeable cellophane dialysis membrane with M.wt. cut off $(<10000)$ dalton. The dialysis sac containing the suspension in (Step III) was dialyzed against $0.1 \mathrm{M}$ ammonium bicarbonate, was stirred with a magnetic stirrer overnight at $4{ }^{\circ} \mathrm{C}$. The solution of dialysis was changed three times (per 3 hours) during dialysis (Robyt and White, 1987). The protein of the dialyzed suspension was used to estimate enzyme activity by modified Lowry method (Schacterle and Pollack, 1973). 


\section{Step V: Freeze-dryer (Lyophilization) technique}

The protein of the dialyzed enzyme (Step IV) was concentrated using a freeze-dryer (Lyophilization).

\section{Step VI: Gel filtration chromatography using Sephadex G-50 and Sephadex G-100}

The sephadex gel G-50 and G-100 supplied as a powder were suspended in adequate amont of distilled water so that when it was stirred it allows the incorporated air bubbles to escape rapidly to the surface. It was then allowed to swell in water bath for 3 hours at $90{ }^{\circ} \mathrm{C}$ to complete swelling. This suspension was used for column packing and sample application (Robyt and White, 1987).

In the present study, the column used was $2.0 \times 90 \mathrm{~cm}$ which contain gel sephadex at a height of $(85) \mathrm{cm}$. The exclusion limit for sephadex G-50 is (30000) Dalton, while sephadex G-100 is (150000) (Robyt and White, 1987).

A concentrated sample (4) $\mathrm{ml}$ of the protein material (from Step V) was applied on the top of a bed sephadex G-50 and the results applied on the top of a bed sephadex G-100, followed by buffer solution (0.05 M Tris-HCl, $\mathrm{pH} 8.0$, and $0.2 \mathrm{M} \mathrm{NaCl})$.

Elution of the protein materials was carried out at a flow rate for sephadex G-50 column at (75) $\mathrm{ml} /$ hour with a definite time (4) min, but for sephadex G-50 column a flow rate $(62) \mathrm{ml} /$ hour with a definite time (5) min. using buffer solution $(0.05 \mathrm{M}$ Tris- $\mathrm{HCl}, \mathrm{pH} 8.0$, and $0.2 \mathrm{M} \mathrm{NaCl})$ as eluant. The fractions were collected using a fraction collector. The protein compounds in each fraction collected were detected by the absorbance at wave length (280) $\mathrm{nm}$ using UV/Visible Spectrophotometer. Peaks were detected from the plot of absorbance versus elution volumes. PON1 was determined in each fraction (Burtis et al., 2012).

Step VII: Freeze-dryer (Lyophilization) technique

The enzyme fraction from step (VI) which was obtained from gel filtration was dried using a freeze-dryer (Lyophilization) technique to obtain a powder or a concentrated protein. The enzyme was kept in a deep freeze at $-20^{\circ} \mathrm{C}$ in a tight sample tube to be used in further investigations.

\section{Step VIII: Electrophoresis}

Samples from step VII which were applied on Sodium Dodecyl Sulphate Poly Acrylamide Gel Electrophoresis (SDS-PAGE) using slab electrophoresis unit quick fit instrumentation (Laemmli, 1970).

\section{Animals and Experimental protocol}

Thirty five white Albino male rats, weighing 200- 300 gm were used in this study; they were obtained from and maintained in the animal house of the Veterinary College, University of Mosul under conditions of controlled temperature. Rodent food rich in nutrient and tap water were used as bedding. The animals were divided into five groups of seven animals each and treated as follow: Group I- received single intraperitoneal (IP) dose of normal saline, this group served as a negative control. Group II - received single IP dose of cisplatin $(10 \mathrm{mg} / \mathrm{kg})$, this group served as positive control. Group III- pretreated with IP dose of PON1 isolated alone ( $1 \mathrm{mg} / \mathrm{kg} / \mathrm{day})$. Group IV and V- animals pretreated with IP dose of isolated PON1 $(0.5 \mathrm{mg}$ and $1 \mathrm{mg} / \mathrm{kg} /$ day respectively) for 5 successive days before and 5 successive days after single IP cisplatin $(10 \mathrm{mg} / \mathrm{kg})$. Animals were anesthetized by ether, blood was collected directly by orbital sinus puncture (Intraocularly) and poured into plain tubes (Atta et al., 1983), the clot was dispersed with glass rod and then centrifuged at $3000 \mathrm{Xg}$ for 15 minute; the serum was used within 2 days for the estimation of alkaline phosphatase (ALP)(Kind and King, 1954), aspartate aminotransferase (AST) (Reitman and Frankel, 1975), alanine aminotransferase (ALT) (Reitman and Frankel, 1975), creatine kinase (CK) (Szasz et al., 1976), total bilirubin(TB) (Martinek, 1966) and malondialdehyde (MDA) (Muslih et al., 2002). The data presented as Mean $\_$SD. The significance of the differences between the mean 
values were calculated using unpaired student's $t$-test. $p$-values equal or less than 0.05 were considered to be significantly different (Indrayan and Sarmukaddam, 2001).

\section{Enzyme purification}

\section{RESULTS AND DISCUSSION}

The results predicted that the enzyme activity was found in the (67)\% of a saturation ammonium sulfate precipitates. As shown in Table (1), the specific activity was increased after dialysis. This might be due to the removal of the small molecules (Below 14000 Dalton) and increasing the purification of PON1.

\section{Gel filtration separations}

This technique was applied to separate the protein as a source of enzyme, which was obtained after dialysis and using a column containing sephadex G-50 and G-100 gel as shown in (step V). The result (Fig. 1) indicated that there is mainly one peak for PON1in sephadex G-50 and after lypholization injected to G-100, was mainly one peak (A) (Fig. 2). The elution volume of peak (A) was $(180.4) \mathrm{ml}$. The specific activity of the enzyme peak (A) was (4.809 U/mg protein) with 147 folds of purification compared to initial extract Table (1). In other studied, established that two allozymic forms of esterases account for the paraoxonase activity present in human serum (Playfer et al., 1976; Smolen et al., 1991, Huang et al., 1995).

Table 1: Partial purification steps of paraoxonase-1 (PON1) from the amniotic fluid

\begin{tabular}{|c|c|c|c|c|c|c|c|}
\hline Purification stage & $\begin{array}{c}\text { Volume } \\
\text { taken } \\
(\mathbf{m l})\end{array}$ & $\begin{array}{c}\text { Protein } \\
\text { conc. } \\
(\mathbf{m g} / \mathbf{m l})\end{array}$ & $\begin{array}{c}\text { Activity } \\
(\mathbf{U} * \mathbf{m l})\end{array}$ & $\begin{array}{c}\text { Total } \\
\text { activity } \\
(\mathbf{U})\end{array}$ & $\begin{array}{c}\text { Sp.activity } \\
\text { (U/mg } \\
\text { protein) }\end{array}$ & $\begin{array}{c}\text { Folds of } \\
\text { Purification }\end{array}$ & $\begin{array}{c}\text { Recovery } \\
\%\end{array}$ \\
\hline Amniotic fluid & 220 & 2.89 & 0.095 & 20.9 & 0.0328 & 1 & 100 \\
\hline $\begin{array}{c}\text { Precipitate by } \\
\left(\mathbf{N H}_{\mathbf{4}} \mathbf{S}_{\mathbf{2}} \mathbf{S O}_{\mathbf{4}}(\mathbf{6 7 \%} \text { \%) }\right.\end{array}$ & 33.5 & 4.11 & 0.39 & 13.065 & 0.0948 & 3 & 62.5 \\
\hline Supernatant & 190.0 & 0.81 & 0.033 & 6.27 & 0.0407 & 1.2 & 30 \\
\hline Dialysis & 35.5 & 1.97 & 0.36 & 12.78 & 0.183 & 6 & 61.1 \\
\hline $\begin{array}{c}\text { Sephadex G-50 } \\
\text { (Fractions)Peak }\end{array}$ & 50.9 & 0.61 & 0.54 & 27.486 & 0.8852 & 27 & 52.6 \\
\hline $\begin{array}{c}\text { Sephadex G-100 } \\
\text { (Fractions) Peak A }\end{array}$ & 24.8 & 0.21 & 1.01 & 25.048 & 4.809 & 147 & 47.9 \\
\hline
\end{tabular}

$\mathrm{U}^{*}$ : a mount of paraoxonase-1 (PON1) catalyzing the formation of one micromole of product per min under optimum conditions. 


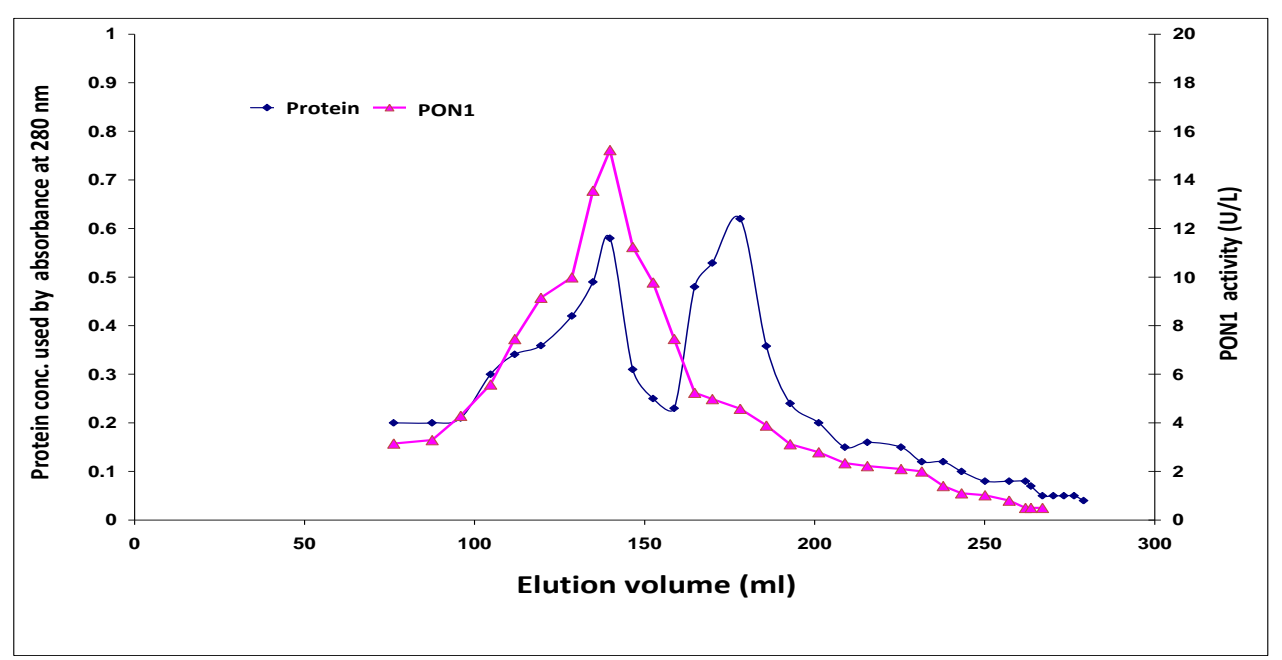

Fig. 1: Elution profile Paraoxonase-1 (PON1) for amniotic fluid on sephadex G-50.

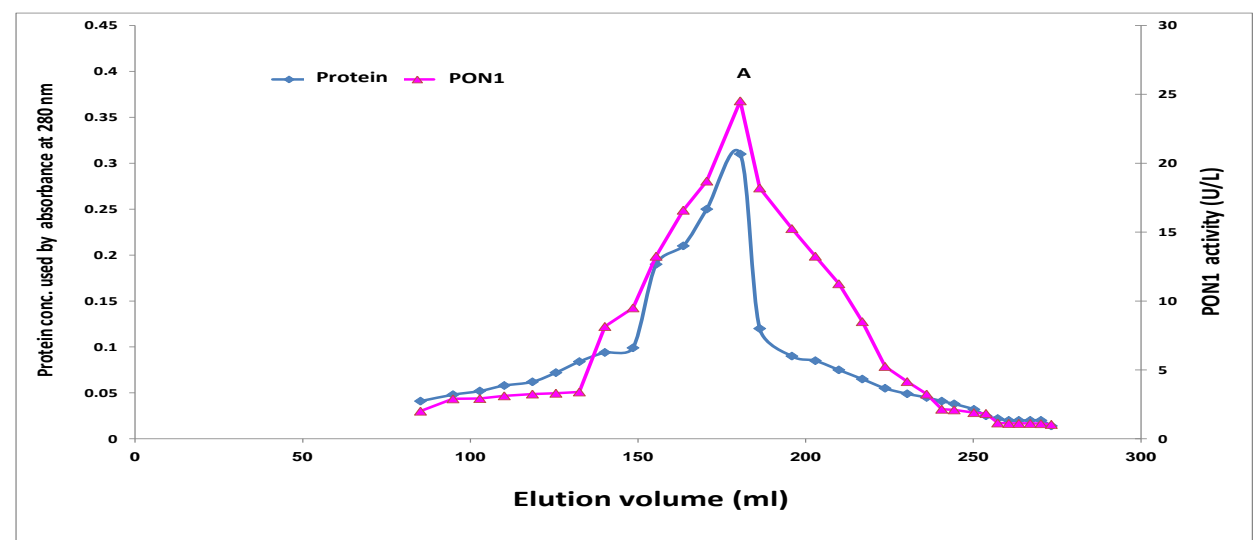

Fig. 2: Elution profile paraoxonase-1 (PON1) for amniotic fluid on sephadex G-100.

\section{Molecular weight determination of PON1 by gel filtration}

The molecular weight of peak (A) as a source of PON1 was determined by the gel filtration chromatography using sephadex G-100 column $(2 \times 85) \mathrm{cm}$ calibrated with known molecular weight proteins that were listed in Table (2).

Table 2: Elution volumes of known molecular weight materials on sephadex G-100.

\begin{tabular}{|c|c|c|}
\hline Materials & $\begin{array}{c}\text { Molecular weight } \\
(\text { Dalton) }\end{array}$ & $\begin{array}{c}\text { Elution volume } \\
(\mathbf{m l})\end{array}$ \\
\hline Blue dextran (Void volume $\left(\boldsymbol{V}_{\circ}\right)$ ) & 2000000 & 91.2 \\
\hline Hexokinase & 100000 & 112.9 \\
\hline Bovine serum albumin & 67000 & 132.8 \\
\hline a- amylase & 58000 & 151.9 \\
\hline Egg albumin & 45000 & 170.7 \\
\hline Pepsin & 36000 & 248.9 \\
\hline Papain & 23000 & 273.1 \\
\hline Tryptophan (Internal volume $\left(\boldsymbol{V}_{\mathbf{i}}\right)$ ) & 204 & $180.4 *$ \\
\hline Unknown (peak A ) & 43873 & \\
\hline
\end{tabular}

* This value was obtained from Fig. (2). 
A plot of logarithmic molecular weight of each material versus the elution volumes indicated in Table (2) gives a straight line as illustrated in Fig. (3).

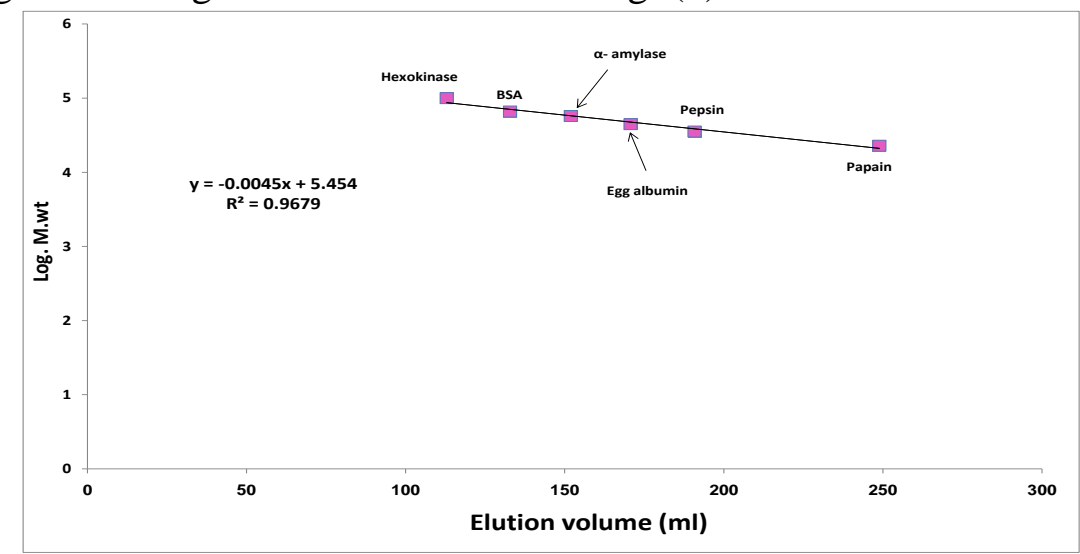

Fig. 3: A plot of the logarithm molecular weights of known proteins versus elution volume on a sephadex G-100.

The molecular weight of unknown protein compound separated by the column chromatography as shown in (step V) was determined from the standard curve, which was represented by Fig. (3). The comparative molecular weight of peak (A) as a source of PON1 is approximately equal to $(43873 \pm 350)$ Dalton.

\section{Molecular Weight Determination by SDS-PAGE}

The electrophoretic mobility of PON1 using SDS-PAGE. The enzyme migrated as a single band in amniotic fluid only as shown in Fig. (4) with an apparent molecular weight of (43682 \pm 278$)$ Dalton which was determined using known molecular weight compounds as shown in Fig. (5).

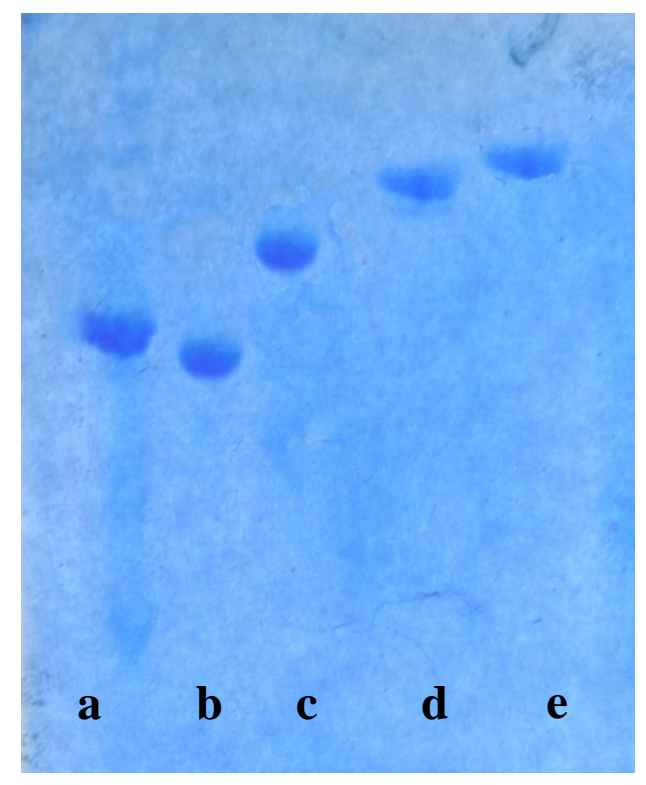

Fig. 4: Protein patterns obtained by SDS- polyacrylamide gel electrophoresis of partially purified PON1 from amniotic fluid. The tubes from left to right contained $50 \mu \mathrm{g}$ of standard protein employed to calibrate the columns were:

a. PON1 separated. b. Pepsin (M.wt. 36000). c. Egg albumin (M.wt. 45000). d. Bovin serum albumin (BSA) (M. wt. 67000). e. Hexokinase (M.wt. 10000). 


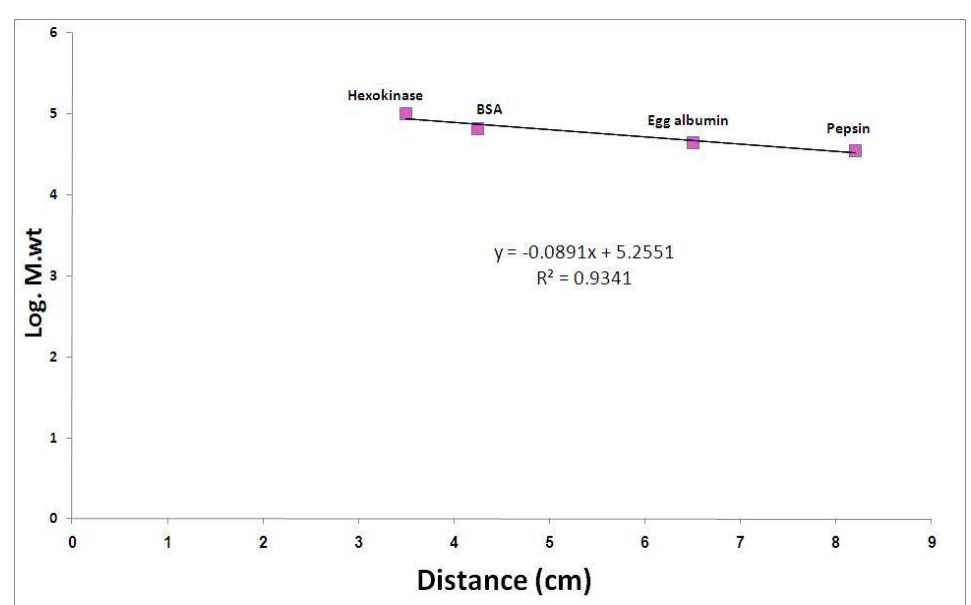

Fig. 5: Calibration curve for molecular weight estimation of PON1 by SDS-polyacrylamide gel electrophoresis using known molecular weight proteins

To confirm the purity of the enzyme, SDS polyacrylamide gel electrophoresis (SDS-PAGE) was performed and a single protein band was observed at approximately M.wt 43682 Dalton, this result are in a good agreement with other reported results from Demir et al., 2011 showing M.wt 43000 Dalton in human serum and with M.wt of approx. 45000 for Rodrigo et al., 1997.

\section{Optimum conditions for PON1 activity}

To develop assay conditions where PON1 from amniotic fluid shows a maximum activity, a series of experiments were performed. These included enzyme concentration, $\mathrm{pH}$ of the assay conditions, incubation time, incubation temperature and substrate concentration (Murray et al., 2009).

\section{Effect of enzyme concentration on PON1 activity}

It is important to establish that the activity varies linearly and decreased finally with enzyme concentration. The activity of the enzyme was measured in the presence of different concentrations of partially purified enzyme from AF between (10-100) $\mu \mathrm{g} / \mathrm{ml}$ as shown in Fig. (6).

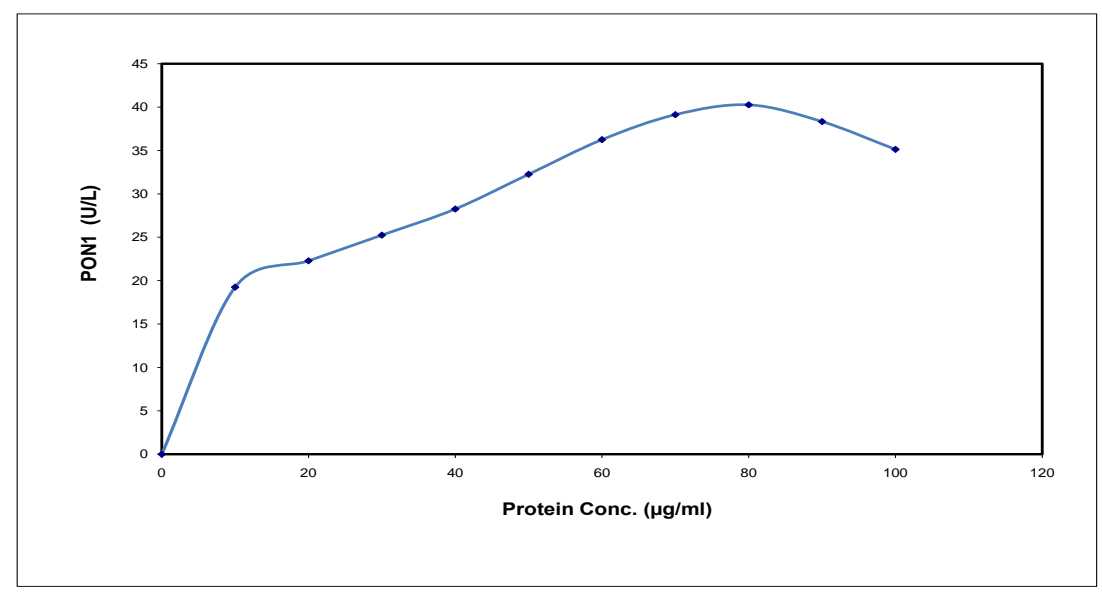

Fig. 6: Effect of different protein concentrations on PON1 activity

The result indicated that the enzyme activity increased by increasing the concentration of protein as a source of the enzyme. These result agree with other research (Cunha Bastos et al., 1999) using isolated PON1 from liver of Pacu, Piaractus Mesopotamicus Holmberg. For the next experiment $(80) \mu \mathrm{g} / \mathrm{ml}$, as a source of the enzyme was selected for determination other optimum conditions. 


\section{Effect of Buffer Solution}

\subsection{Effect of buffer concentration on PON1 activity:}

The activity of enzyme was measured in the presence of different concentrations of buffer solution within the range $(0.06-0.18) \mathrm{mol} / \mathrm{liter}$ of Tris- $\mathrm{HCl}$ buffer at $\mathrm{pH}$ 8.5. Maximum activity was obtained using (0.14) mol/liter of Tris-HCl buffer (Fig. 7).

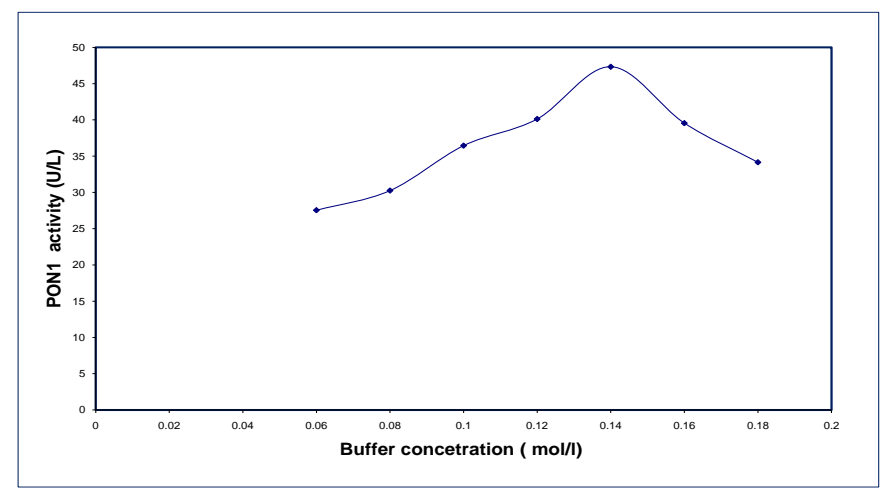

Fig. 7: Effect of buffer concentrations on PON1 activity.

\subsection{Effect of pH on the PON1 activity:}

The influence of $\mathrm{pH}$ on the activity of PON1 was investigated using $(80 \mu \mathrm{g} / \mathrm{ml})$ as a source for enzyme from $\mathrm{AF}$ in $(0.14) \mathrm{mol} / \mathrm{liter} \mathrm{Tris}-\mathrm{HCl}$ buffer. The assay conditions were conducted in the same manner as described earlier at $\mathrm{pH}$ range of $(5.5-10.0)$. Maximum PON1 activity was obtained at $\mathrm{pH}(8.0)$ as indicated in (Fig. 8). Extremes of $\mathrm{pH}$ above of 8.0 can lead to denaturation of the enzyme and decreased activity, because the structure of the catalytically active site for the enzyme depends on the ionic character of the amino acid side chains (Harvey and Ferrier, 2014). In other studies, the optimum $\mathrm{pH}$ of the enzyme was about (8.5) from rat liver (Rodrigo et al., 1997) and from the liver of Pacu, Piaractus Mesopotamicus Holmberg (Cunha Bastos et al., 1999).

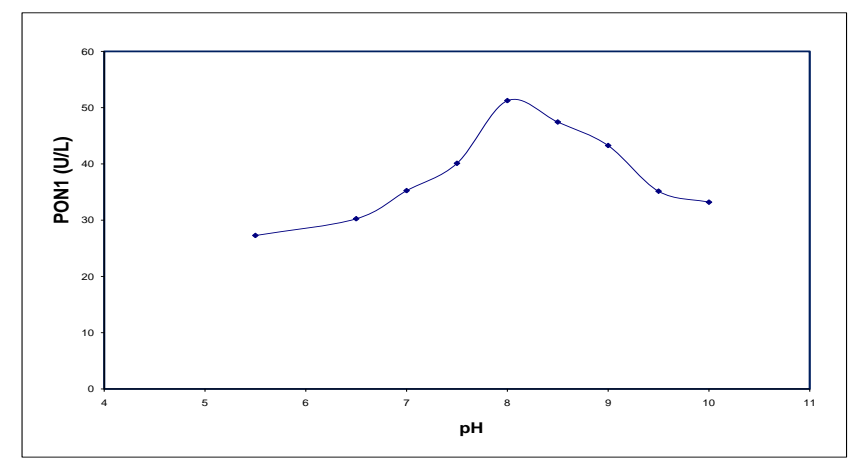

Fig. 8: Effect of pH on PON1 activity using (0.14)mol/liter phosphate buffer and $(80 \mu \mathrm{g} / \mathrm{ml})$ as a source for the enzyme.

\section{Incubation time as a function of enzyme activity}

To determine the stability of PON1 activity under assay conditions, a series of experiments were performed at different time intervals. The results indicated that maximum enzyme activity was obtained after (7) min. in $\left(37^{\circ} \mathrm{C}\right)$ incubation (Fig. 9). 


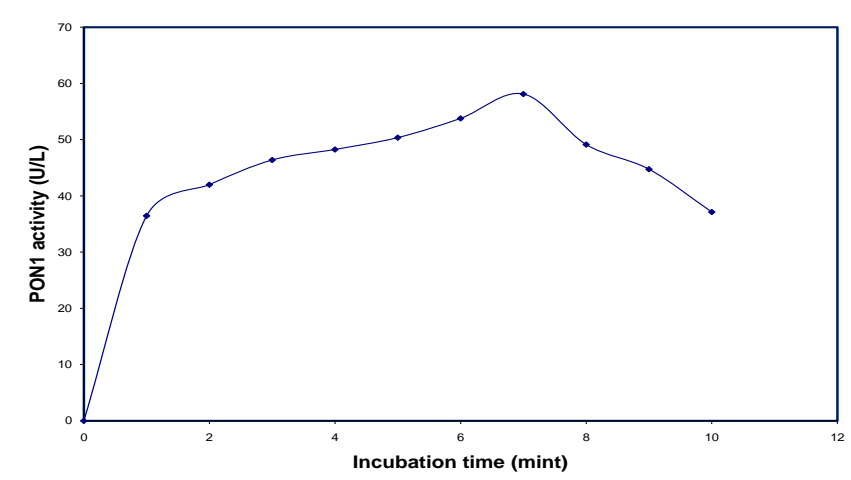

Fig. 9: Effect of incubation time on PON1 activity.

\section{Effect of temperature on PON1 activity:}

It has been found that as the temperature increased, there was a concave up increase in the enzyme activity until it reached a maximum value at a temperature of $\left(45{ }^{\circ} \mathrm{C}\right)$ then dropped gradually after that (Fig. 10). This increase is the result of the increased number of molecules having sufficient energy to pass over the energy barrier and form the products of the reaction. Further elevation of the temperature results in a decrease in reaction velocity as a result of temperature-induced denaturation of the enzyme (Harvey and Ferrier, 2014).

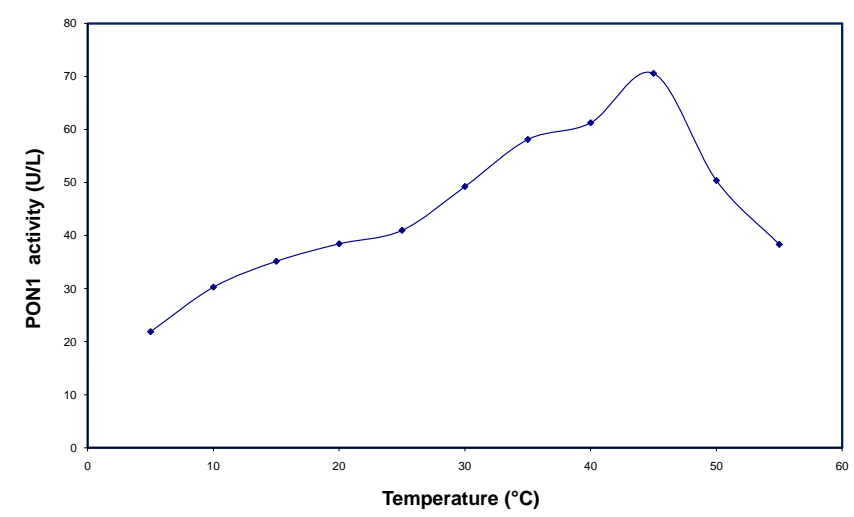

Fig. 10: Effect of temperature $\left({ }^{\circ} \mathrm{C}\right)$ on PON1 activity.

Rat liver paraoxonase appeared in Rodrigo et al., 1997 relatively stable at $47.5{ }^{\circ} \mathrm{C}$, with $50 \%$ of its activity remaining after $30 \mathrm{~min}$ of incubation. However, at 52.5 and $55^{\circ} \mathrm{C}$, rapid inactivation occurred after 15 and 60 min respectively.

\section{Effect of substrate concentration on the enzyme activity:}

To determine the effect of substrate concentration [Paraoxon] on the enzyme activity, a series of experiments were performed where the concentration of the substrate was varied (Fig. 11). 


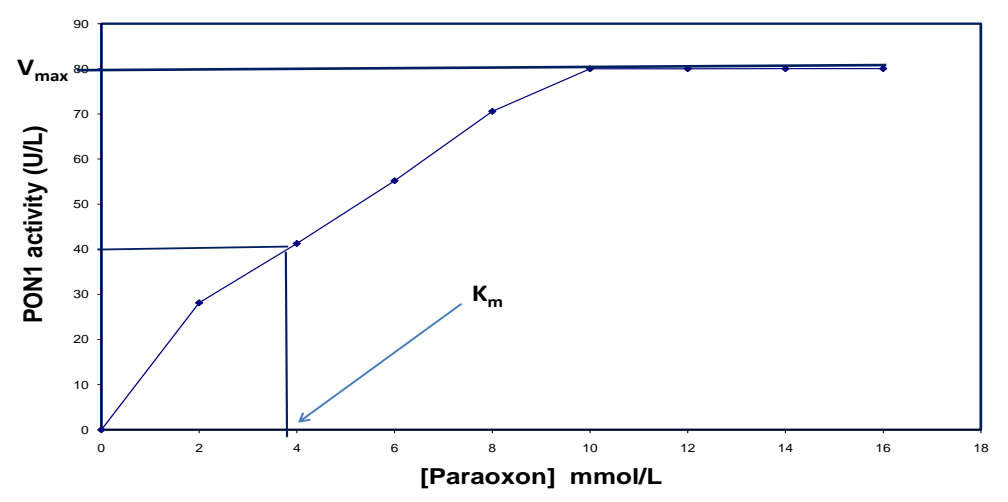

Fig. 11: Effect of substrate concentration [Paraoxon] on the activity of purified PON1.

The Michaelis-Menten constant $\left(K_{\mathrm{m}}\right)$ and maximum velocity $\left(V_{\max }\right)$ of the enzyme were determined from Figs. (11 and 12). The lineweaver-Burk plot by plotting the reciprocal of the initial velocity versus the reciprocal of the substrate concentration. A linear relationship was obtained in Figure (12) giving a $K_{\mathrm{m}}$ value of $(3.79 \mathrm{mmol} / \mathrm{liter})$ and $V_{\max }(80.0 \mu \mathrm{mol} / \mathrm{min}$.). Other report fund the $K_{\mathrm{m}}$ for liver paraoxonase as $1.69 \mathrm{mmol} / \mathrm{liter}$ (Rodrigo et al., 1997). Karacabey Merino reported $49 \times 10^{-6} \mathrm{mmol} /$ liter and $122 \mathrm{U} / \mathrm{mL}$ for $K_{\mathrm{m}}$ and $V_{\max }$ values respectively (Arslan et al., 2011).

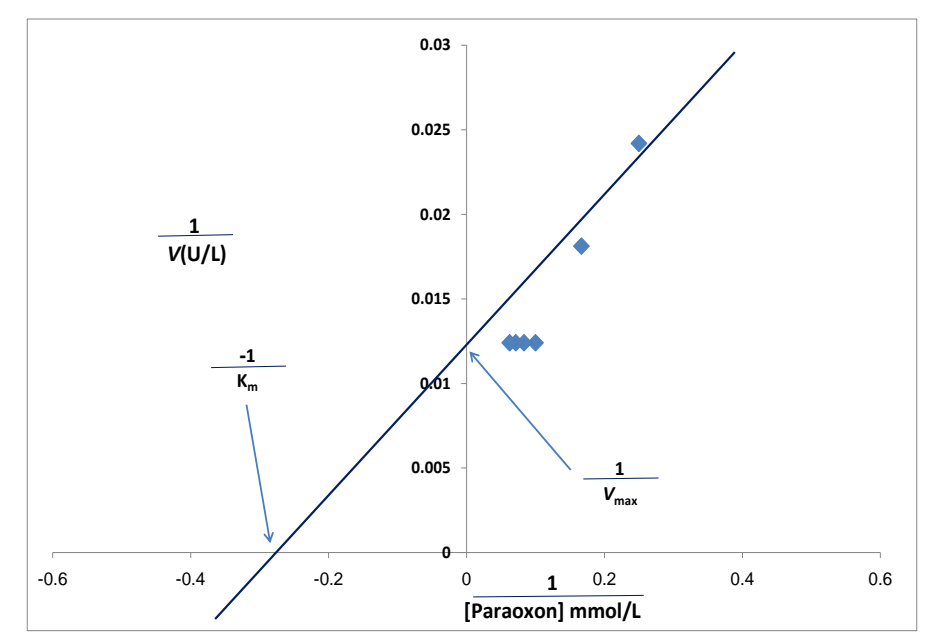

Fig. 12: Line Weaver-Burk plot of partially purified PON1 from amniotic fluid .

\section{Optimum conditions of the purified paraoxonase-1:}

The optimum conditions of the purified Paraoxonase-1 from amniotic fluid are shown in the following Table (3):

Table 3: Optimum conditions of the purified Paraoxonase-1.

\begin{tabular}{|c|c|c|c|c|c|c|c|}
\hline $\begin{array}{c}\text { Enzyme } \\
\text { Conc. } \\
(\mu \mathrm{g} / \mathrm{ml})\end{array}$ & $\begin{array}{c}\text { Buffer } \\
\text { Conc. } \\
\text { (mol/liter) }\end{array}$ & pH & $\begin{array}{l}\text { Time } \\
(\mathbf{m i n})\end{array}$ & $\begin{array}{l}\text { Temp. } \\
\left({ }^{\circ} \mathrm{C}\right)\end{array}$ & $\begin{array}{r}\text { Parao } \\
\text { xon } \\
(\mathrm{mmo} \\
\mathrm{l} / \mathrm{l})\end{array}$ & $\begin{array}{c}K_{\mathbf{m}} \\
(\mathrm{mmol} / \text { liter })\end{array}$ & $\begin{array}{c}V_{\max } \\
(\mu \mathrm{mol} / \mathrm{mi} \\
\mathrm{n})\end{array}$ \\
\hline
\end{tabular}




\begin{tabular}{|l|l||l|l|l||l|l|l|}
\hline 80 & 0.14 & 8.0 & 7 & 45 & 12 & 3.79 & 80.0 \\
\hline
\end{tabular}

\section{The effect of paraoxonase-1 isolate against cisplatin-induced hepatotoxicity and cardiotoxicity:}

The results and the effect PON1 isolation on the serum levels of ALP, ALT, AST, CK, TB and MDA for the treated animals are listed in Table (4).

The results indicated that the serum levels of ALP, ALT, AST and MDA were significantly elevated in the group II in comparison with the group I ( $\mathrm{p} \leq 0.05)$. While in group IV and group $\mathrm{V}$ the serum levels of ALP, ALT, AST and MDA were significantly reduced.

Table 4 : The effect of PON1 isolation on the serum levels of ALP, ALT, AST, CK, TB and MDA of the treated animals

\begin{tabular}{|c|c|c|c|c|c|}
\hline $\begin{array}{l}\text { Biochemical } \\
\text { parameters }\end{array}$ & $\begin{array}{c}\text { Control } \\
\text { (Normal } \\
\text { saline) } \\
\text { (Group I) } \\
\text { N=7 }\end{array}$ & $\begin{array}{c}\text { Cisplatin } \\
(10 \text { mg/kg) } \\
\text { (Group II) } \\
\text { N=7 }\end{array}$ & $\begin{array}{c}\text { PON1 (1 mg/kg) } \\
\text { alone } \\
\text { (Group III) } \\
\mathbf{N}=7\end{array}$ & $\begin{array}{c}\text { PON1(0.5 } \\
\text { mg/kg) + } \\
\text { cisplatin } \\
\text { (10 mg/kg) } \\
\text { (Group IV) } \\
\text { N=7 }\end{array}$ & $\begin{array}{c}\text { PON1(1 mg/kg) } \\
\text { + cisplatin } \\
\text { (10 mg/kg) } \\
\text { (Group V) } \\
\text { N=7 }\end{array}$ \\
\hline ALP(U/L) & $84.00 \pm 8.11 \mathbf{d}$ & $124.87 \pm 12.11 \mathbf{a}$ & $74.44 \pm 6.27 \mathbf{e}$ & $101.50 \pm 11.16 \mathbf{b}$ & $91.15 \pm 9.28 \mathbf{c}$ \\
\hline ALT(U/L) & $5.1 \pm 0.21 \mathrm{~d}$ & $11.7 \pm 0.97 \mathbf{a}$ & $4.3 \pm 0.59 \mathbf{e}$ & $7.25 \pm 0.88 \mathbf{b}$ & $6.41 \pm 0.91 \mathbf{c}$ \\
\hline AST (U/L) & $5.4 \pm 0.34 \mathbf{d}$ & $16.6 \pm 1.25 \mathbf{a}$ & $5.1 \pm 0.71 \mathbf{e}$ & $7.81 \pm 0.96 \mathbf{b}$ & $6.73 \pm 0.84 \mathbf{c}$ \\
\hline CK (U/L) & $78.73 \pm 5.73 \mathbf{d}$ & $148.87 \pm 10.4 \mathbf{a}$ & $75.73 \pm 6.21 \mathbf{e}$ & $128.71 \pm 7.93 \mathbf{b}$ & $96.57 \pm 3.59 \mathbf{c}$ \\
\hline TB (mg/dL) & $1.11 \pm 0.11 \mathbf{d}$ & $4.35 \pm 0.71 \mathbf{a}$ & $0.98 \pm 0.13 \mathbf{e}$ & $2.01 \pm 0.23 \mathbf{b}$ & $1.78 \pm 0.19 \mathbf{c}$ \\
\hline MDA $(\mu \mathrm{mol} / \mathrm{L})$ & $0.83 \pm 0.027 \mathbf{d}$ & $2.91 \pm 0.052 \mathbf{a}$ & $0.62 \pm 0.077 \mathbf{e}$ & $1.36 \pm 0.023 \mathbf{b}$ & $1.12 \pm 0.014 \mathbf{c}$ \\
\hline
\end{tabular}

- $\quad$ Each value represents Mean + SD .

- Different letters horizontally a, b, c, d, e, indicate that the mean are different significantly at $\mathrm{P} \leq 0.05$.

The cytotoxic effect of cisplatin is enhanced by the elevation of the dose, however, at higher doses, the less common toxic effects, such as hepatotoxicity and cardiotoxicity, may arise (Santos et al., 2007). It has been suggested that oxidative stress is an important mechanism of cisplatin-induced toxicity possibly due to depletion of reduced glutathione (GSH) (Yilmaz et al., 2004) The oxidative stress through the generation of reactive oxygen species, decreases antioxidant defense system including antioxidant enzymes and non enzymatic molecules (GSH) which are the major alterations in the cisplatin toxicity (Kart et al., 2010; Kocik et al., 2012). Also many studies reported that there were a significant elevation in the hepatic malondialdehyde (MDA) and reduction in the level of antioxidant enzymes in rats treated with cisplatin (Yilmaz et al., 2005; Mansour et al., 2006). Transaminases for (ALT and AST) as well as, ALP are the most sensitive biomarkers directly implicated in the extent of cellular damage and toxicity because they are cytoplasmic in location and are released into the circulation after cellular damage (Stockham and Scott, 2002). Elevation of the serum levels of the hepatic enzymes and bilirubin are the indicators for impaired liver functions (Iseri et al., 2007) (Table 4, group II). Cisplatin elevates serum cardiotoxicity enzymatic indices (AST and CK) and causes severe histopathological lesions in cardiac tissues (Al-Majed et al., 2006). The effect could be a secondary event following cisplatininduced lipid peroxidation of cardiac membranes with the consequent increase in the leakage of AST and CK from cardiac myocytes (Al-Majed et al., 2006). There are many evidence dealing with the administration of antioxidants that may be effective in ameliorating cisplatin-induced cardiotoxicity, like acetyl-L-carnitine, DL- $\alpha$-lipoic acid and silymarin, which have been proven to possess antioxidant potentials and appear to be potential candidates to ameliorate cardiotoxicity associated with cisplatin use in rats (Mansour et al., 2008).

The improvement of liver and cardiac markers when animals pretreated with IP dose of isolated PON1 (0.5mg and $1 \mathrm{mg} / \mathrm{kg} /$ day respectively) for 5 successive days before and 5 successive days after single IP cisplatin (10mg/kg) (Table 4, Group IV and V) is due to contribute in of PON1 
by removing toxic compounds and inhibit lipid oxidation in low density lipoproteins (LDLs) (Povey, 2010). Thus, it might be an important detoxifying enzyme and may play a protective role against the development of various diseases. Therefore PON1 could be defined as an antioxidant enzyme (Deakin and James, 2004; Ekinci and Beydemir, 2009). It is able to inhibit coppercatalyzed LDL oxidation in vitro and the inflammatory response induced by oxidized LDL in the arterial wall (Harangi, 2002). The second important function of PON1 is its anti-atherogenic activity. Serum PON1 exists with HDL in plasma and acts to prevent the oxidation of plasma lipoproteins (Aviram, 1999). PON1 is effective on lipid peroxides and also on hydrogen peroxide therefore, it is considered to have peroxidase like activity (Memişoğullar and Orhan, 2010). Serum PON1 activity is especially important for the protection of LDL phospholipids against oxidation. In the protective effect against atherosclerosis, LDL has different antiatherogenic features such as protection from free radical induced oxidation of LDL cholesterol in artery wall (Aviram, 1999). In addition to LDL, PON1 protects HDL too which is a carrier of lipid peroxide (Azarsiz and Sqzmen, 2000). PON1 protects lipoproteins and arterial cells against oxidation, probably by hydrolyzing lipid peroxides such as specific oxidized cholesteryl esters and phospholipids. It was suggested to contribute to the antioxidant protection conferred by HDL on LDL oxidation (Mackness et al., 1991).

\section{REFERENCES}

Abu-Surrah, A.S.; Kettunen, M. (2006). Platinum group antitumor chemistry: design and development of new anticancer drugs complementary to cisplatin, Curr. Med. Chem.13, $1337-1357$.

Akinbi, H.T.; Narendran, V.; Pass, A.K.; Markart, P.; Hoath, S.B.(2004). Host defense proteins in vernix caseosa and amniotic fluid. Am. J. Obstet. Gynecol. 191,2090-6.

Alam, M.; Mahajan, M.; Raziuddin, M. ; Singh, T.P.; Yadav, S. (2009). Proteomics-based approach for identification and purification of human phosphate binding apolipoprotein from amniotic fluid. Genetics and Molecular Res. 8 (3), 929-937.

Ali, B.H.; Al Moundhri, M.S. (2006). Agents ameliorating or augmenting the nephrotoxicity of cisplatin and other platinum compounds: a review of some recent research. Food Chem. Toxicol. 44, 1173-1183.

Al-Majed, A.A. (2006). Carnitine deficiency Provokes cisplatin-induced hepatotoxicity in rats. Basic and Clin. Pharmcol. and Toxic.100, 145-150.

Al-Majed, A.A.; Sayed-Ahmed, M.M.; Al-Yahya, A.A.; Aleisa, M.A.; Al-Rejaie, S.S.; AlShabanah, O.A. (2006). Propionyl-L-carnitine prevents the progression of cisplatin induced cardiomyopathy in a carnitine-depleted rat model. Pharmacol. Res. 53,278-286.

Arslan, M.; Erzengin, M.; Demir, D. (2011).Comparison of serum paraoxonase-1 (PON1) activities among different sheep breeds in Turkey . J. Animal Veter. Adv. 10(4), 489-494.

Atta, A.H.; Shalaby M.A.; Shokry I. M.; Ahmed A.A.(1983). Interaction between oral hypoglycemic and antibiotics on blood glucose level of normal fasted and alloxan diabetic rats. Vet. Med. J. 31(1), 11-18.

Aviram, M. (1999). Does paraoxonase play a role in susceptibility to cardiovascular disease. Mol. Med. Tod. 5,381-386.

Azarsiz, E.; Søzmen, E.Y. (2000). Paraoxonase in clinical biochemistry, Türk Biyokimya Dergisi, 25(3), 109-119.

Burtis, C.A.; Ashwood, E.R.; Bruns, D.E. (2012). "Tietz Textbook of Clinical Chemistry and Molecular Diagnostics". FElsevier Inc. USA. pp.356, 368.

Cunha Bastos, V.L.F.; Ana Rossini, E.F.; Ceccarelli, P.S.; Senhorini, J.A.; Cunha Bastos, J. (1999). Praoxonase activity in liver of Pacu, Piaractus Mesopotamicus Holmberg (Characidae). Revta bras. Zool. 15 (5), $677-685$. 
De Jongh, F.E.; van Veen, R.N.; Veltman, S.J.; de Wit, R.; van der Burg, M.E.; van den Bent, M.J. (2003). Weekly high-dose cisplatin is a feasible treatment option: analysis on prognostic factors for toxicity in 400 patients. British J. Cancer. 88, 1199-206.

Deakin, S.; James, R. (2004). Genetic and environmental factors modulating serum concentrations and activities of the antioxidant enzyme paraoxonase-1. Clin. Sci., 107, 435-447.

Demir, N.; Nadaroğlu, H.; Demir, Y.; Güngör, A.(2011). An, In Vitro, Study of some pesticides on the activity of human serum paraoxonase (PON1). Jordan J. Chem. 6(4), 439-451.

Eckerson, H.W.; Romson, J.; Wyte, C.; La Du, B.N.(1983). The human serum paraoxonase polymorphism: identification of phenotypes by their response to salts. Am. J. Hum. Genet. 35, 214-227.

Ekinci, D.; Beydemir, S. (2009). Evaluation of the impacts of antibiotic drugs on PON 1: A major bioscavenger against cardiovascular diseases. Eur. J. Pharmacol. 617, 84-89.

Furlong, C.E.; Richter, R.J.; Min, W.K.; Kim, J.Q.(2001). Genetic variations of the paraoxonase gene in patients with coronary artery disease. Clin. Biochem. 34, 475-481.

Gowri, M.S.; Van der Westhuyzen, D.R.; Bridges, S.R.; Anderson, J.W. (1999). Decreased protection by HDL from poorly controlled type 2 diabetic subjects against LDL oxidation may be due to the abnormal composition of HDL. Arterioscler. Thromb. Vasc. Biol. 19, 2226-2233

Harangi, M. (2002). Paraoxonase effect on oxidative DNA damage .Thesis for the degree of Ph.D. University of Debrecen, Medical and Health Science Center.

Harvey, R.A.; Ferrier, D.R. (2014). " Lippincott's Illustrated Reviews: Biochemistry. "5th ed. Lippincott Williams and Wilkins, China. P.20,71,61.

Huang, Y.S.; Woods, L.; Sultatos, L.G. (1995). Solubilization and purification of A-esterase from mouse hepatic microsomes. Biochem. Pharmacol. 48,1273-1280.

Indrayan A.; Sarmukaddam S.B. (2001). "Medical Biostatistics". Marcel Dekker, Inc, USA, pp. 299,303,405.

Iseri, S.; Ercan, F.; Gedik, N.; Yuksel, M.; Alican, I. (2007). Simvastatin attenuates cisplatininduced kidney and liver damage in rats. Toxicology. 230, 256-264.

Kart, A.; Cigremi, Y.; Karaman, M.; Ozen, H. (2010). Caffeic acid phenethyl ester (CAPE) ameliorates cisplatin-induced hepatotoxicity in rabbit. Exp. Toxicol. Pathol. 62 (1), 45-52.

Kind, P.R.N.; King, E.J. (1954). Estimation of plasma phosphatase by determination of hydrolysed phenol with amino-antipyrine. J. Clin. Path. 7, 322-26.

Kocik, M.; Zimovjanova, M.; Petruzelka, L.; Kodydkova, J.; Vavrova, L.; Zak, A. (2012). Oxidative stress after anthracycline therapy in patients with solid tumors. Cas. Lek. Cesk.151(10), 463-7.

Laemmli, U.K. (1970). Cleavage of structural proteins during the assembly of the head of bacteriophage $\mathrm{T}_{4}$. Nature, 227, 680-85.

Muslih R.K.; Al-Nimer M.S.; Al-Zamely O.M.Y.(2002). The level of malondialdehyde after activition with $\left(\mathrm{H}_{2} \mathrm{O}_{2}\right.$ and $\left.\mathrm{CuSO}_{4}\right)$ and inhibation by desferoxamine and molsidomine in the serum of patient with acute myocardial infaraction. Nation. J. Chem. 5,139-148.

Mackness, M.I.; Harty, D.; Bhatnagar, D.; Winocour, P.H.; Arrol, S.; Ishola, M.; Durrington, P.N. (1991). Serum paraoxonase activity in familial hypercholesterolaemia and insulin-dependent diabetes mellitus. Atherosclerosis. 86, 193-199.

Mackness, M.I.; Mackness, B.; Durrington, P.N.; Connelly, P.W.; Hegele, R.A. (1996). Paraoxonase: biochemistry, genetics and relationship to plasma lipoproteins. Curr. Opin. Lipidol. 7, 69-76.

Mansour, H.H.; Hafez, H.F.; Fahmy, N.M. (2006). Silymarin modulates cisplatin induced oxidative stress and hepatotoxicity in rats. J. Biochem. Mol. Biol. 39, 656-661.

Mansour, M.A.; Bakheet, S. A.; Aleisa, A. M.; Al-Rejaie, S. S.; AL-Yahya, A. A.; El-Ameen, M.; Al-Shabanah , O.A.(2008). Protective effect of 6-Gingerol against cardiotoxicity induced by doxorubicin. The Open Pharm. J. 2, 20-23. 
Martinek, R. (1966). Improved micro-method for determination of serum bilirubin. Clin Chim Acta. 9, 61-170.

Memişoğulları, R.; Orhan, N. (2010). Paraoxonase in cancer disease. Konuralp Medical J., 2(2), 2226.

Murray R.K.; Bender D.A.; Botham K.M.; Kennelly P.J.; Rodwell V.W. (2009). "Harper's Illustrated Biochemistry". 28 ed. The McGraw-Hill Companies, USA, Chapter 8.

Playfer, R.; Eze, L.C.; Bullen, M.F.; Evans, D.A.P. (1976). Genetic polymorphism and interethnic variability of plasma paraoxonase activity. J. Med. Genet. 13, 337-342.

Povey, A.C. (2010). Gene-environmental interactions and organophosphate toxicity. Toxicology, 10, 1016.

Primo-Parmo, S.L.; Sornson, R.C.; Teiber, J.; La, Du, B.N. (1996). The human serum paraoxonase/arylesterase gene (PON1) is one member of a multigene family. Genomics. 33(3), 498-507.

Reitman, S.; Frankel, S. (1975). In vitro determination of transaminases activity in serum. Am.J.Clin. Pathol. 28, 56-60.

Robyt, F. J.; White, J. B. (1987). "Biochemical Techniques Theory and Practice". Books / Cole Publishing Com., USA,P.50-83.

Rodrigo, L.; Gil, F.; Hernandez, A.F.; Marina, A.; Vazquez, J.; Pla, A.(1997). Purification and characterization of paraoxon hydrolase from rat liver. Biochem. J. 321, 595-601.

Sanghera, D.K.; Saha, N.; Kamboh, M.I. (1998). DNA polymorphisms in two paraoxonase genes (PON1 and PON2) are associated with the risk of coronary heart disease. Am. J. Hum Genet. 62, 36-44.

Santos, N.A.G.; Martins, N.M.; Curti, C.; Bianchi, M.L.P.; Santos, A.C. (2007). Dimethylthiourea protects against mitochondrial oxidative damage induced by cisplatin in liver of rats. Chem. Biol. Int. 170, 177-186.

Schacterle, G.R.; Pollack, R.L. (1973). A simplified method for the quantitative assay of small amount of protein in biological material. Anal. Biochem. 51, 654-655.

Smolen, A.; Eckerson, H.W.; Gan, K.N.; Hailat, N.; La Du, B.N. (1991). Characteristics of the genetically determined allozymic forms of human serum paraoxonase/arylesterase. Drug Metab. Dispos. 19, 107-112

Stockham, S.L.; Scott, M.A. (2002). "Fundamentals of Veterinary Clinical Pathology". Ames, Iowa State University. Press. P.434-459.

Szasz, G.; Gruber, W.; Bernet, E. (1976). Creatine kinase in serum I. Determination of optimum reaction conditions Clin. Chem. 22, 650.

Tsangaris, G.T.; Kolialexi, A.; Karamessinis, P.M.; Anagnostopoulos, A.K.(2006). The normal human amniotic fluid supernatant proteome. In Vivo 20, 479-490.

Verburg, B.O.; Geelhoed, J.J.; Steegers, E.A.; Hofman, A. (2007). Fetal kidney volume and its association with growth and blood flow in fetal life: The Generation R Study. Kidney Int. 72, 754-761.

Yilmaz, H.R.; Iraz, M.; Sogut, S.; Ozyurt, Z.Y.; Akyol, O.; Gergerlioglu, S. (2004). The effects of erdostiene on the activities of some metabolic enzymes during cisplatin- induced nephrotoxicity in rats. Pharmacolo. Res. 50, 287-290.

Yilmaz, H.R.; Sogut, S.; Ozyurt, B.; Ozugurlu, F.; Sahin, S.; Isik, B. (2005). The activities of liver adenosine deaminase, xanthine oxidase, catalase, superoxide dismutase enzymes and the levels of malondialdehyde and nitric oxide after cisplatin toxicity in rats: protective effect of caffeic acid phenethyl ester. Toxicol. Ind. Health. 21, 67-73.

Yousef, M.I.; Saad, A.A.; El-Shennawy, L.K.(2009). Protective effect of grape seed proanthocyanidin extract against oxidative stress induced by cisplatin in rats. Food Chem. Toxicol. 47, 1176-1183. 